\title{
Coastal Fringe Habitat Monitoring using Kite Aerial Photography: A Remote Sensing-based Case Study
}

\author{
B.D. Madurapperuma ${ }^{1,2^{*}}$ and J.E. Dellysse ${ }^{2}$ \\ ${ }^{1}$ Department of Forestry and Wildland Resources, Humboldt State University, USA \\ ${ }^{2}$ Department of Environmental Science and Management, Humboldt State University, USA
}

Date Received: 2017-11-26

Date Accepted: 2018-06-15

\begin{abstract}
Monitoring coastal ecosystem resilience for climatic and/or anthropogenic vulnerabilities is challenging with moderately resolution Landsat images. A simple, low-cost Kite Aerial Photograph platform (KAP) was vital to obtain high-resolution images for a small area to develop coastal GIS models. This study examines post-tsunami relief in two coastal shrub ecosystem and a mangrove ecosystem in terms of vegetation bioshield mass and sea level rise perspectives. A KAP platform was created using two light-weight automatic cameras with dual bandpass Red-NIR filters, a Picavet stabilizing rig, a GPS tracker and a Parafoil Kite. The KAP images were processed to build mosaic images, orthorectified and geo-referenced Digital Elevation Model (DEM) using structure-from-motion (SFM) and remote sensing software (Agisoft PhotoScan and ENVI respectively). KAP has been utilised for coastal mapping under three scenarios: (i) object-orient feature extraction for discriminate Prosopis juliflora, an invasive alien species, and texture analysis for coastal shrub and herbaceous vegetation classification (ii) DEM for sea level rise, and (iii) Normalized Difference Vegetation Index (NDVI) for mangrove bioshield mass estimation. The image processing produced a point cloud with an average density of 35 points $/ \mathrm{m}^{2}$; a DEM with $17 \mathrm{~cm}$ resolution; and an orthophoto mosaic with an average resolution of $4.0 \mathrm{~cm}$. The results showed that object orient feature extraction can discriminate Prosopis juliflora from the coastal shrubs with $62 \%$ accuracy, while supervised classification accuracy was 51\%. Mangrove vegetation in Rekawa was discriminated from grassland and other coastal shrub vegetation types at $\geq 4$ NDVI threshold resulted in 0.33 ha of mangroves ( $28 \%$ of 1.15 ha of the total area). The Kahandamodara beach coastal vegetation was dominant by Ipomoea pes-capre with $26 \%$ coverage. In conclusion, KAP has a wide potential to bridge science with high spatial/temporal resolution in-situ data for coastal habitat mapping, where the researchers can utilize the data within a low-cost budget.
\end{abstract}

Keywords: kite mapping, coast, DEM, mangrove, NDVI

\section{Introduction}

Coastal habitats are dynamic ecosystems that are critically important to conserve and provide better ecological services. In Sri Lanka, diverse coastal habitats are vulnerable to natural and/or anthropogenic disturbances such as tsunami, climate change, land-use/cover change and invasion of alien species etc. For example, coastal highlands in Sri Lanka transform to different land-uses often due to human settlements (Chen and Ye, 2014), agriculture (Dellysse and Madurapperuma, 2017), fish hatcheries (Cattermoul and Devendra, 2002), and tourist industries (Savundranayagam et al., 1994).

*Correspondence: bdm280@ humboldt.ed

ISSN 2235-9370 Print/ISSN 2235-9362 Online (C) University of Sri Jayewardenepura 
This leads to change coastal geomorphology as well as coastal biomass loss causing environmental vulnerabilities such as flooding, cyclones and sea level rise. Therefore, monitoring historical land-use change along the coastline is important to make sustainable land-use planning in future to mitigate climatic and/or anthropogenic disturbances.

A wide-scale mapping conducts using medium resolution images, such as Landsat images (Dellysse and Madurapperuma, 2017; Dellysse et al., 2017) due to limited availability of high-resolution images. For example, a coastal GIS model was developed to measure the changes to coastal vegetation and assess the resilience of several coastal biomes of Sri Lanka Pre and Post 2004 tsunami based on landuse categories; paddy, garden, coconut, dense forest, open forest, water bodies and other types of landuses (Dellysse and Madurapperuma, 2017). Furthermore, Dellysse et al. (2017), reported that humaninduced land uses such as paddy and garden were more vulnerable than natural vegetation for tsunami disaster in Hambantota district. These land-use categories were used to extrapolate changes and as indicators of health and resilience for several coastal biological services or biomes; mangrove forests, salt marshes, home gardens and coastal scrubs (Bambaradeniya et al., 2005).

These biological services offer protection from previous and current coastal land disturbances i.e. increased wave action from Sea Level Rise (SLR) and large, infrequent actions i.e., tsunamis. Furthermore, these biomes and root structures offer coastal stabilization of terrestrial soil structures and prevent coastal ecosystem degradation while acting as a biosheild. Almost half of Sri Lanka's southern coastline was affected by the devastating effects of seawater inundation and related debris contamination post-tsunami (Illangasekare, 2006). Much of the coastal and inland ecosystems were severely affected by salt water and a host of other contaminants (Dellysse et al., 2017). When analyzing the effects on these ecosystems by wave action, inland flooding from SLR and tsunamis the inevitable consequences and vulnerability of these low lying coastal communities and habitats becomes apparent.

Kite Aerial Photography (KAP) is very reliable for coastal mapping in Sri Lanka due to low-cost, high resolution, limited regulation and easy flying during high wind velocity. KAP has been used for different coastal applications such as coral reefs mapping (Currier, 2015), sediment depositional characteristics (Bryson et al., 2016), coastal erosion (Madurapperuma et al., 2017a) and sea level rise (Madurapperuma et al., 2017a).

This study examines post-tsunami relief and recovery of coastal shrub and mangrove vegetation in Hambantota utilizing KAP for vegetation bioshield mass characteristics and sea level rise scenarios. There are three main objectives of this study. One is to compare Prosopis juliflora (an invasive alien species) extent in coastal habitat using feature extraction and supervised classification methods. The second is classify coastal vegetation using high-resolution kite aerial images and estimate the mangrove vegetation extent using NDVI threshold. The third objective is to create DEM and elevation profiles in coastal habitat to determine the sea level rise vulnerabilities.

\section{Methodology}

\subsection{Study Area}

The preliminary study on coastal land-use change pinpointing tsunami in Hambantota using Landsat images (Dellysse and Madurapperuma, 2017) were subjected to a fine scale assessment using high-resolution kite aerial photographs to understand long-term recovery from boxing day tsunami. We sampled three tsunami study sites in Hambantota (adopted from Bambaradeniya et al., 2006; site 20: beach near Sea Spray Hotel in Hambantota, site 12: Kahandamodara beach, and site 10: Rekawa turtle sanctuary) by acquiring kite aerial photographs to observe vegetation recovery at two coastal shrub and a mangrove vegetation (Figure 1). 


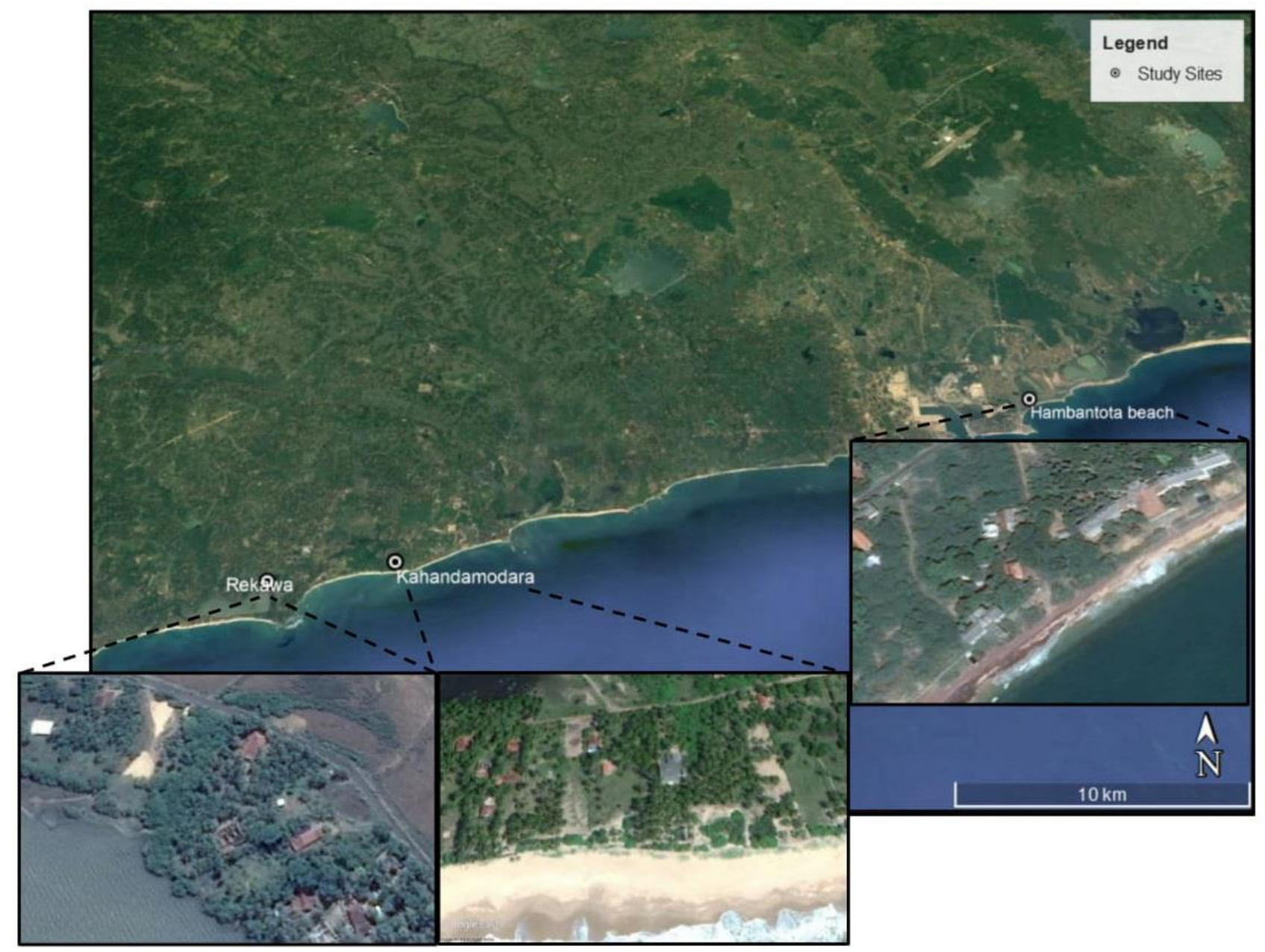

Figure 1: Google Earth Image showing the three study sites of Hambantota district: two coastal shrub vegetation (Kahandamodara and Hambantota beach areas) and a mangrove vegetation (Rekawa).

\subsection{Equipment and methods}

A KAP platform was created using two light-weight automatic cameras with dual bandpass RedNIR filters, Picavet stabilizing rig (Bryson et al., 2012), GPS tracker and a Parafoil kite (Figure 2). The kite was flown 10-15 minutes under 15-20 mph wind speed. Aerial images collected using two downwards-facing Canon Power Shot A490 digital camera (one color and one near-infrared) at $15 \mathrm{~m}$ altitude. A perpendicular transects from shoreline to interior coastal vegetation were made to cover an average extent of one ha. Ground control points were collected from land-use features, such as rock, fishing boats, fence posts and trees using a Garmin GPS receiver with $5 \mathrm{~m}$ accuracy (Madurapperuma et al., 2017a). 

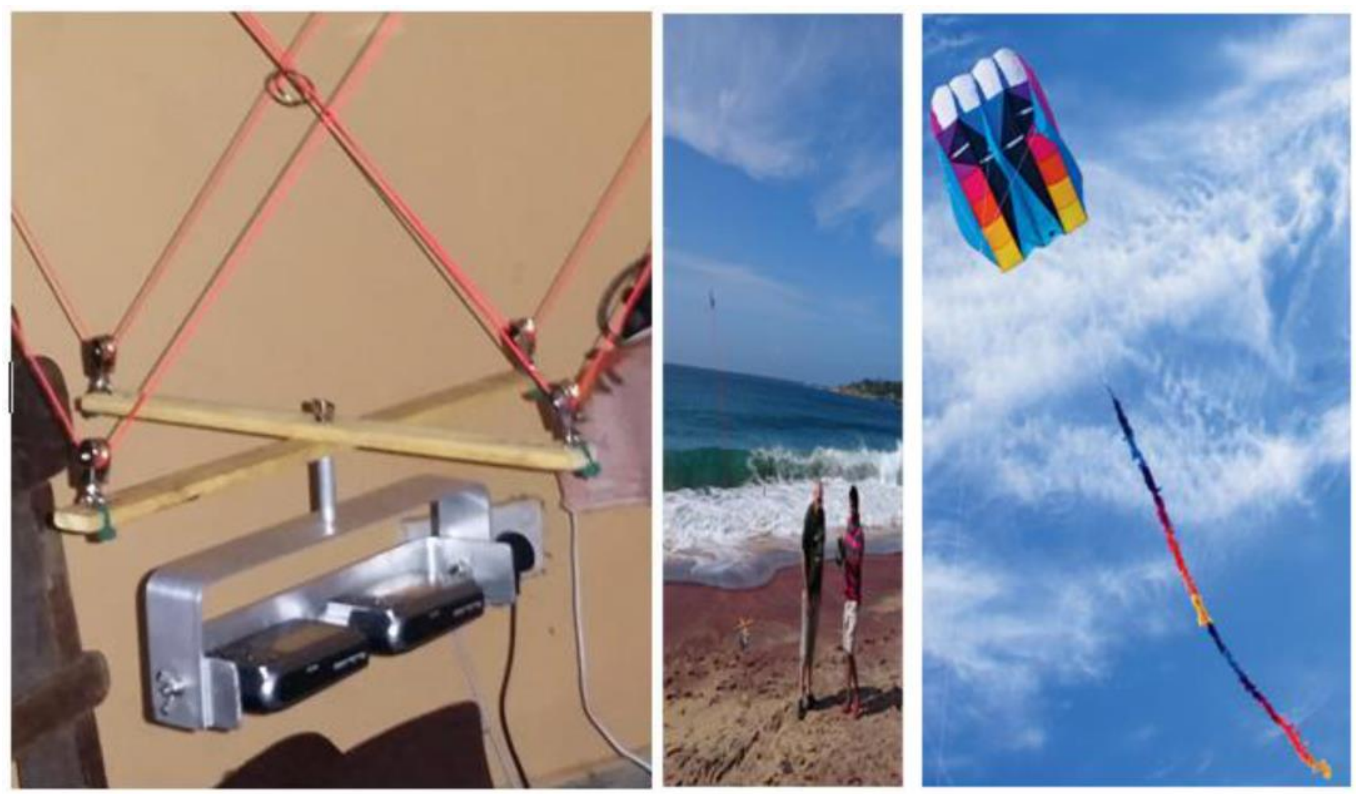

Figure 2: KAP Platform build-up with two cameras (left), attached Picavet stabilizing rig to a string (middle) and Parafoil kite in the air (right).

\subsection{Image processing and analysis}

The high-resolution KAP images were processed to build mosaic images, orthorectified and georeferenced DEMS using structure-from-motion (SfM) and remote sensing software (Agisoft PhotoScan and ENVI respectively). High-resolution orthomosaic imagery has been utilized for coastal mapping under three scenarios: (i) vegetation classification using object-oriented feature extraction, supervised classification and unsupervised classification (Madurapperuma et al., 2018) (ii) Digital Elevation Model for sea level rise (Madurapperuma al., 2017a) (iii) Normalized Difference Vegetation Index (NDVI) for vegetation bioshield mass estimation (Madurapperuma al., 2017b).

\section{Vegetation classification}

The coastal shrub vegetation in Hambantota beach area was co-dominant by two invasive alien species viz., Prosopis juliflora in the overstory and Opuntia dillenii in the understory. The study estimated the $P$. juliflora extent using two methods, such as object-oriented feature extraction and supervised classification (Madurapperuma al., 2018). A 150 random points were generated from the vegetated area to perform the accuracy assessment for $P$. juliflora occurrence habitats to evaluate the accuracy of two classification methods.

Another coastal habitat in Kahandamodara beach area was mapped using texture analysis and unsupervised classification. Texture Analysis is a method of calculating varying texture differences in each pixel by comparing its neighboring pixels (Srinivasan and Shobha, 2008). In order to perform texture analysis, mean and standard deviation of band 3 (red band) and band 1 (blue band) that sensitive to vegetation signature was performed using focal statistics function in ArcGIS ${ }^{\odot}$. The composite image was created combing the mean and standard deviation images and natural color image. The composite image (eight bands together) was classified into five classes using an unsupervised classification and then the classes further collapsed into three land-use classes, namely coastal shrub, coastal herbaceous and open space.

\section{Sea level rise (SLR)}

The DEM that created from the KAP images and ground control points was used to create SLR model. A Google Earth image was used to create elevation profile from shoreline to upland vegetation that is useful to get the inundation levels when creating SLR. For example, the elevation for the study area 
ranged from 3 to $9 \mathrm{~m}$ and therefore the SLR was created for 3, 5, 7 and $9 \mathrm{~m}$ inundation levels (A detailed SLR adopted to this study is

available at:

http://gsp.humboldt.edu/olm_2016/Activities/GSP_270/09_SeaLevelRise_Rasters/Lab9_RasterAnalysisI. html).

Normalized difference vegetation index (NDVI)

The NDVI was calculated using red and NIR bands of the KAP image using band math function of $\mathrm{ENVI}^{\circledR}$ using the following equation.

NDVI $=($ NIR - Red $) /(I R+R e d)$

The mangrove vegetation was extracted using NDVI threshold $\geq 4$ as suggested by Vo et al. (2013).

\section{Results}

The KAP is useful for multi-scale assessment of coastal habitat vulnerabilities that produces detail information, for example, coastal biomass health to pinpoint tsunami mitigation measures. The results present here for two coastal shrub vegetation and a mangrove vegetation in Hambantota showing the results of vegetation classification, sea level rise model and NDVI for assessing of vegetation biosheild health.

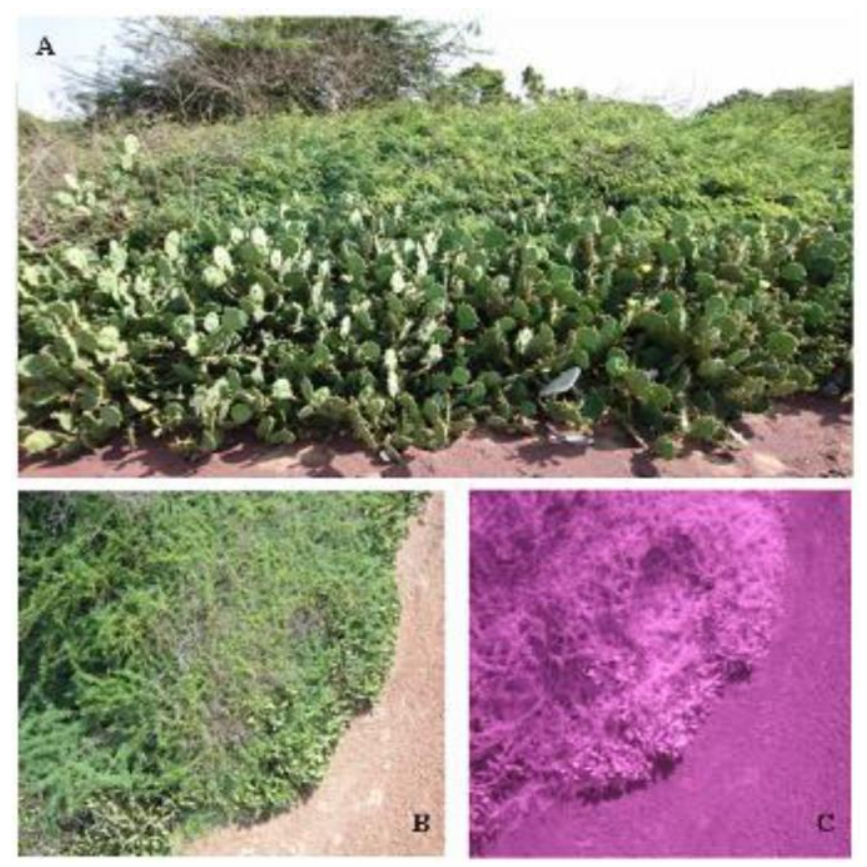

Figure 3: Vegetation bioshield at Hambantota coastal area (6.132588 N; 81.130718E). The overstory vegetation dominant by Prosopis juliflora and understory vegetation dominant by Opuntia dillenii (A).

The KAP images of coastal vegetation at 15 m altitude: (i) RGB color (B) and (ii) NIR color (C).

Vegetation bioshield at Hambantota coastal area is studied using high-resolution kite aerial photographs. A coastal shrub vegetation of Hambantota beach was mainly dominant by Prosopis juliflora in the overstory and Opuntia dillinii in the understory (Figure 3).

Two classification techniques were used to compare the Prosopis juliflora acreage in the coastal shrub vegetation. Feature extraction techniques estimated 1.32 ha of $P$. juliflora, while supervised 
classification estimated 3.11 ha. The accuracy assessment for the two methods revealed that comparatively high accuracy for feature extraction technique (Figure 4).

KAP images at Kahandamodara beach area were used to classify coastal shrub and herbaceous vegetation using texture analysis and unsupervised classification. The extent of the area is one ha. The unsupervised classification identified three classes, such as coastal shrub, coastal herbaceous and open space (Figure 5). The major vegetation type is coastal shrub dominant by Pandanus odoratissimus, Scaevola takkada and Calotropis gigantea (Bambaradeniya et al., 2006). The leading herbaceous species is Ipomoea pes-capre. The total coverage of coastal shrub and coastal herbaceous was $55 \%$ and $26 \%$ respectively.

A

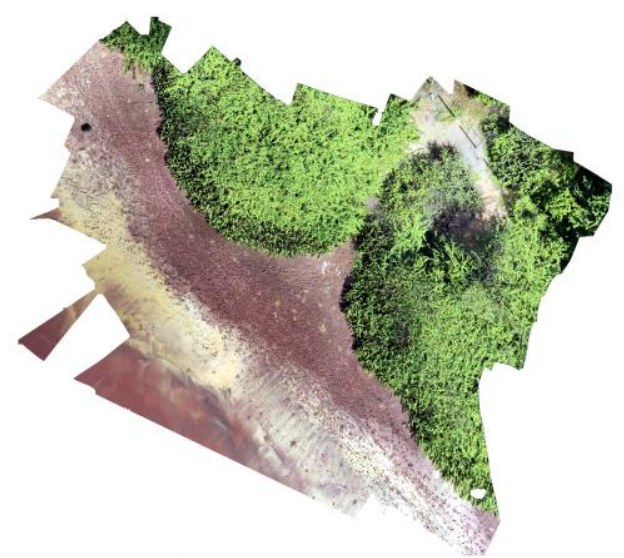

C

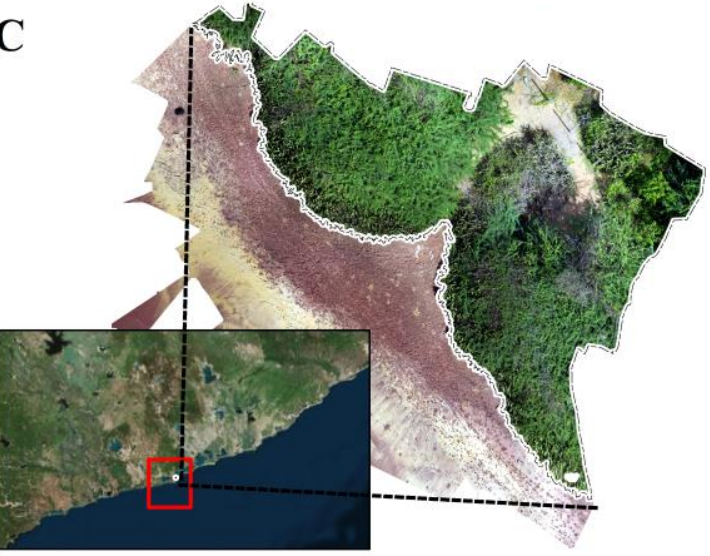

B

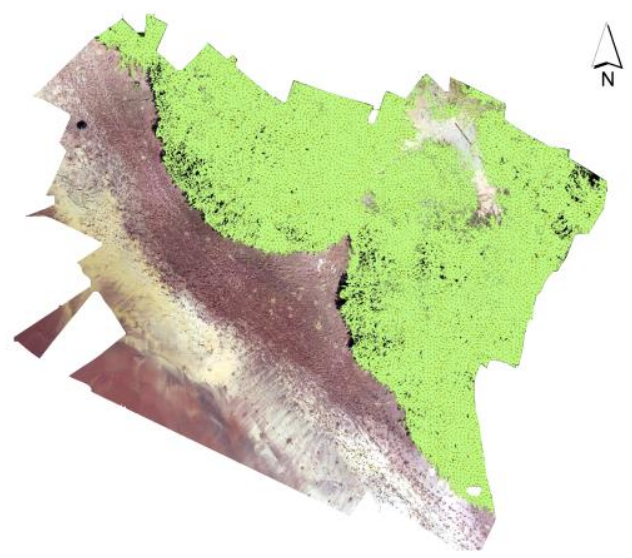

Classification Method Total Area (ha) Classification Accuracy

Feature Extraction

Supervised

Prosopis juliflora

Vegetation Boundary

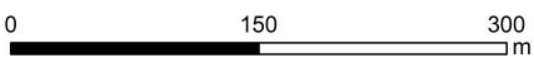

Projection: WGS 84 UTM Zone 44N

Figure 4: Estimation of Prosopis Juliflora extent in coastal shrub vegetation in Hambantota (6.132548 N; 81.130816 E) using feature extraction (A) and supervised classification (B) techniques. A locator map and high-resolution kite aerial photograph are shown in Fig 1C. 

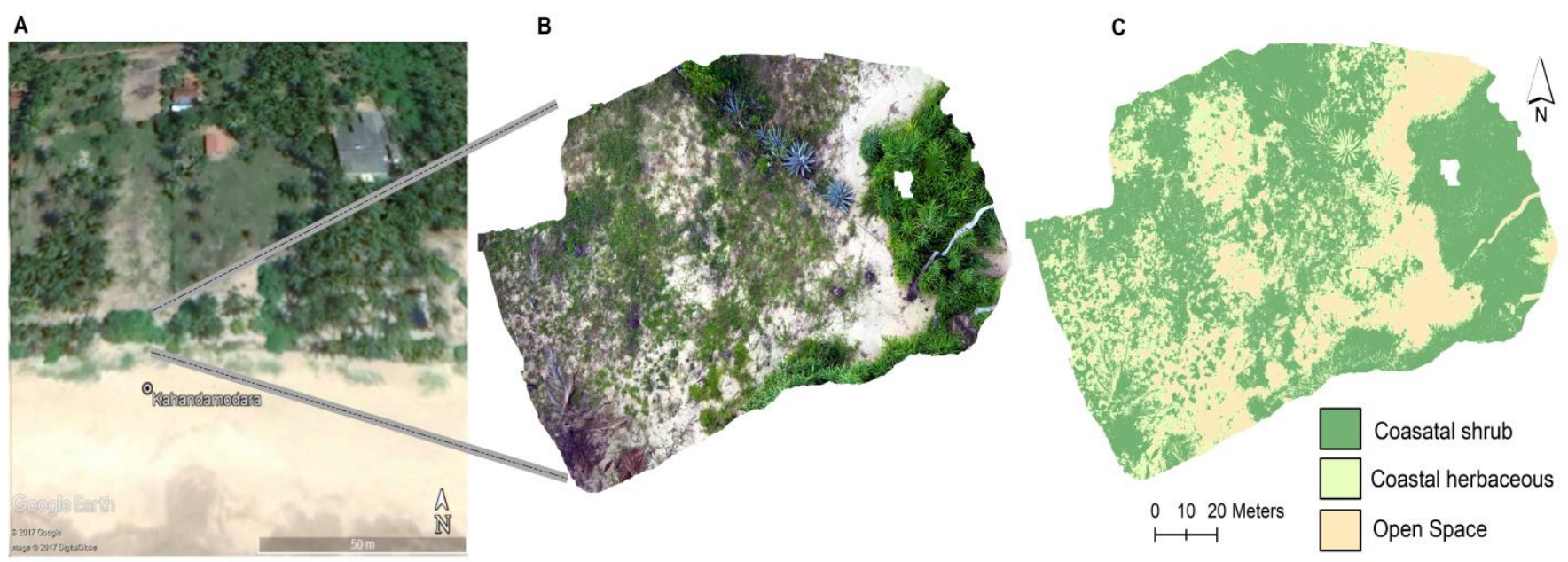

Figure 5: Vegetation bioshield at Kahandamodara beach area (6.063593 N; 80.89767 E). A Google Earth image of Kahandamodara beach area (A), Color image (B) and texture analysis and unsupervised classified image $(\mathrm{C})$.

The elevation profile from coastline to inland vegetation was created using the Google Earth imagery and the elevation was ranged from $3 \mathrm{~m}$ to $9 \mathrm{~m}$ (Figure 6). This elevation range was used to create sea level rise model at $2 \mathrm{~m}$ intervals, i.e. $3 \mathrm{~m}, 5 \mathrm{~m}, 7 \mathrm{~m}$ and $9 \mathrm{~m}$. The SLR results show that $3 \mathrm{~m}$ elevation inundates coastline, while $9 \mathrm{~m}$ elevation floods some coastal vegetation (Figure 7).

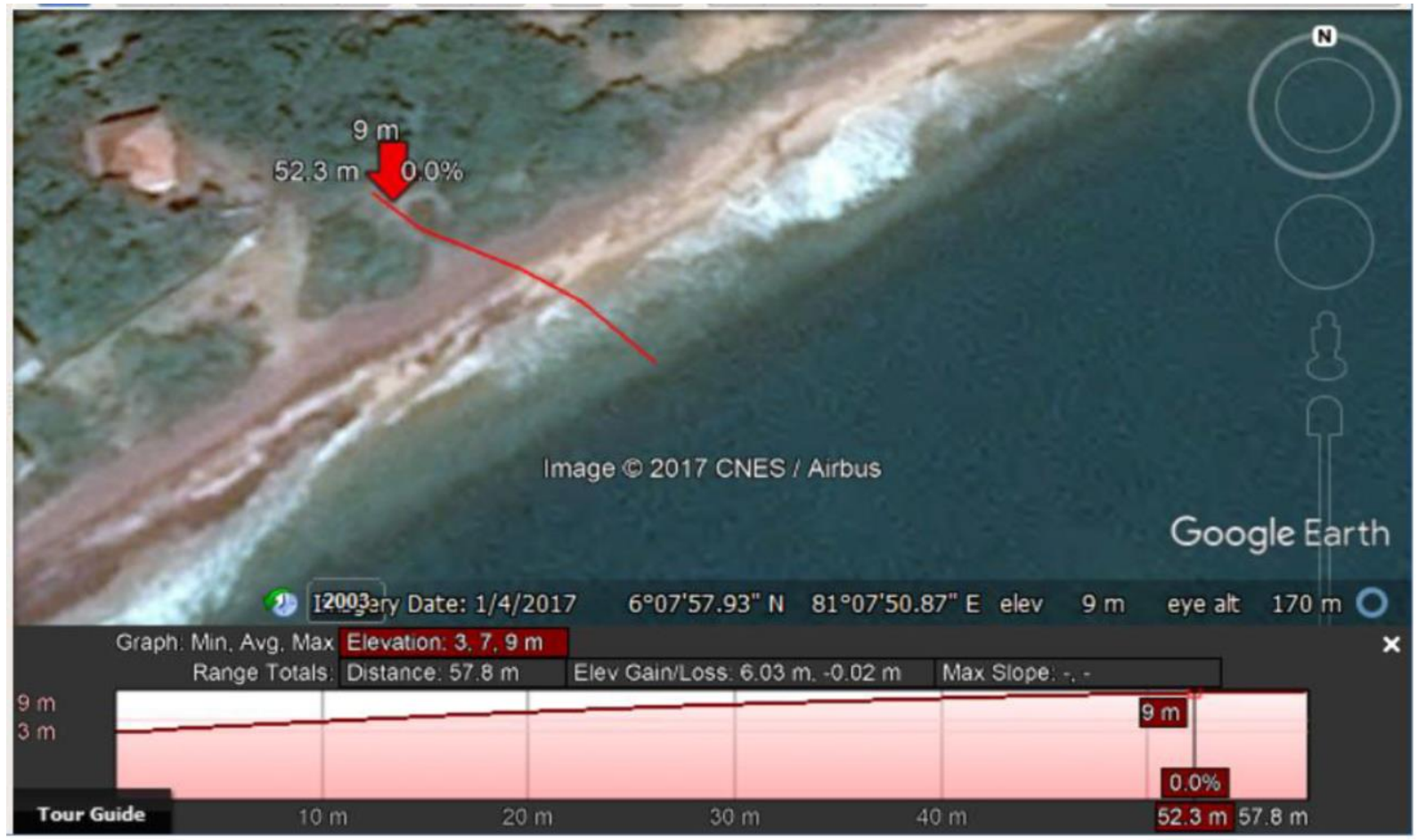

Figure 6: Elevation profile of the study area from the sea level $3 \mathrm{~m}$ to the upland $9 \mathrm{~m}$. 


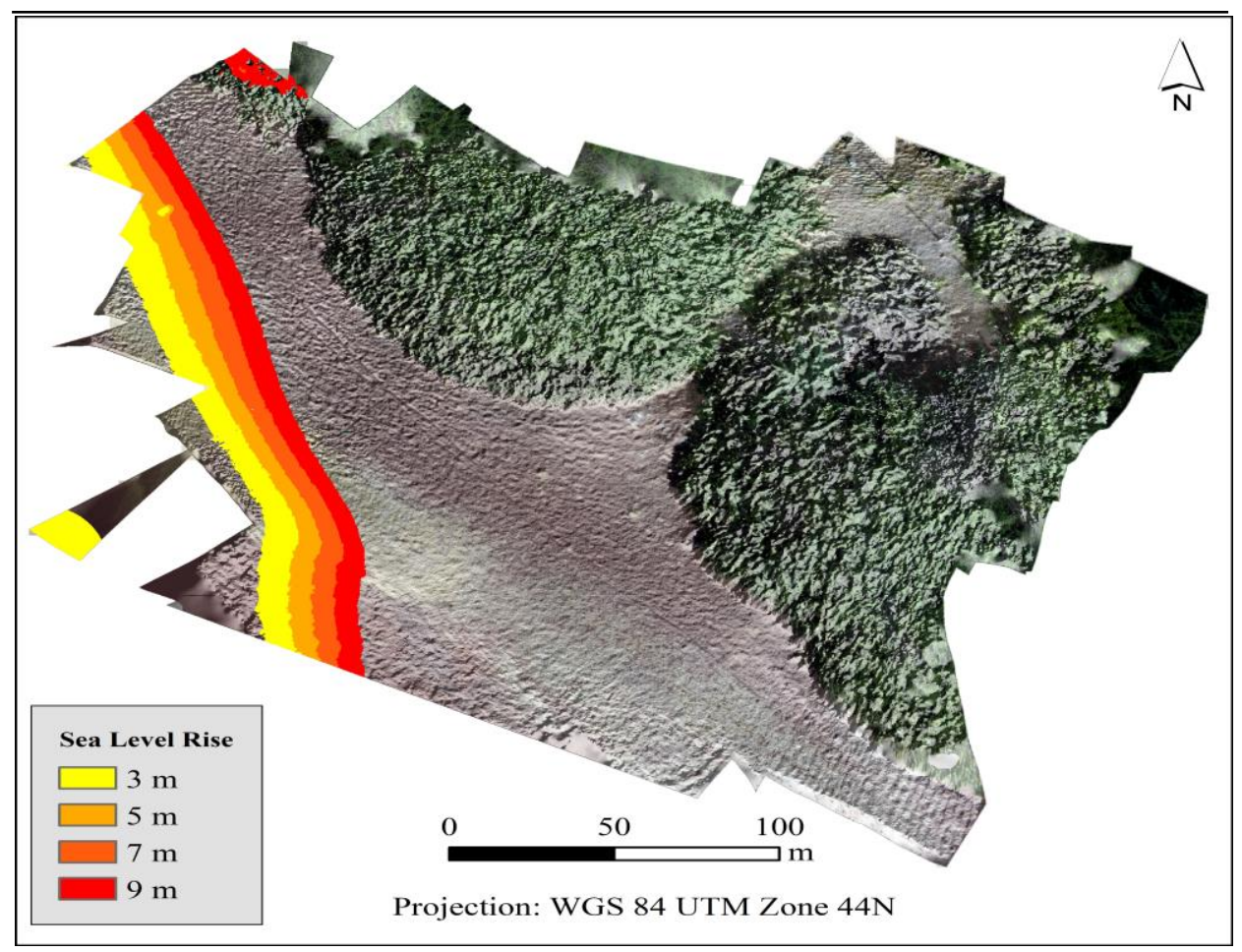

Figure 7: Sea level rise model created from DEM at Hambantota coastal shrub vegetation.
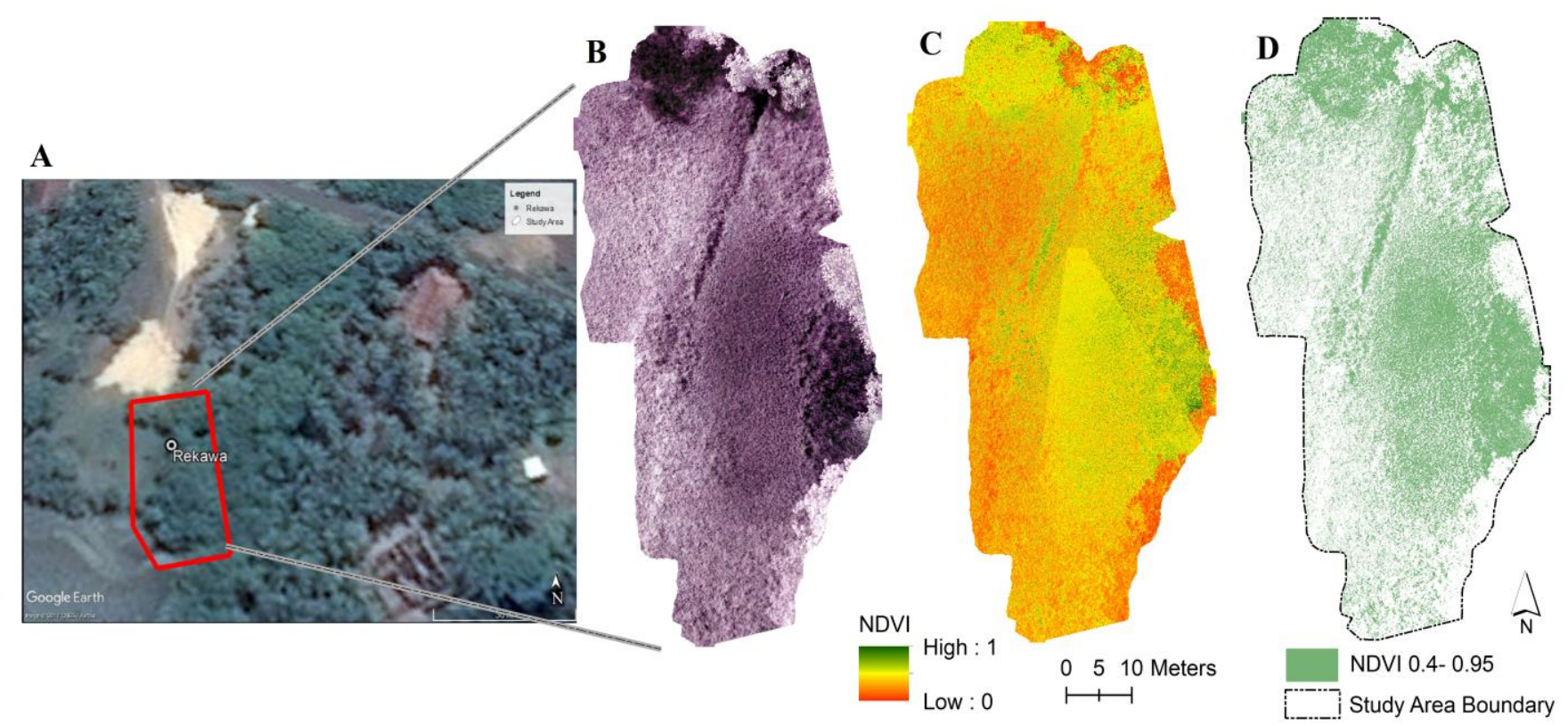

Figure 8: Vegetation bioshield at Rekawa mangrove area (6.056456 N; 80.854696 E). A Google Earth image of Rekawa mangrove area and its surrounding (A). A NIR image (B) and the NDVI image (C) mangrove vegetation.

We assessed vegetation health at Rekawa mangrove restoration area in Hambantota using NDVI that was derived from NIR images (Figure 8). The vegetation cover in the area is 1.15 ha with $4 \mathrm{~cm}$ spatial resolution and the point cloud density is 56 points $/ \mathrm{m}^{2}$. Mangrove acreages within the study area 
were estimated using NDVI threshold of 0.4 that adopted by Vo et al. (2013) and the NDVI ranged for this study was 0.4 to 0.95 . According to the results, 0.33 ha (28\% of total area) was mangroves and 0.46 ha $(40 \%)$ was grassland and other coastal shrub vegetation.

\section{Discussion}

In the coming decades, the coastal biomes will be primary indicators of ecological, agricultural and sociological health as climate change intensifies the natural forces along the world's coastlines in the coming decades (Liquete et al., 2013). The predicted SLR up to $1.3 \mathrm{~m}$ by 2100 will adversely affect for a small island like Sri Lanka causing flooding, seawater inundation at agricultural lands and coastline erosion (Grinsted et al., 2010). For example, Madurapperuma et al. (2017a) SLR model at Oluvil beach showed that the proposed Oluvil harbor will significantly flood at $1.5 \mathrm{~m}$ level due to severe coastal erosion (Ameer, 2015). Coastal GIS and remote sensing models are useful to recognize spatial patterns of biophysical features of the coast and bioshield mass resilience from SLR and tsunami. Various sensors and algorithms have been utilized in remote sensing for mapping biomass in coastal habitats. Landsat images with moderate resolutions of $(\sim 30 \mathrm{~m})$ have been used for regional coastal vegetation mapping at community levels (i.e., Xie, 2008; O'Donnell and Schalles, 2016; Dellysse and Madurapperuma, 2017; Dellysse et al., 2017). NDVI as a graphical indicator is a widely used algorithm for estimating biomass with in-situ empirical biomass data that plugs into mathematical equations (O'Donnell and Schalles, 2016). However, the Landsat data is limiting when mapping particular species distribution. KAP was acquired at three study sites of Bambaradeniya et al. (2006) and therefore one-to-one habitat characteristics of two sites were compared to evaluate the rehabilitation of coastal vegetation. According to Bambaradeniya et al. (2006) survey, Hambantota beach site was poorly regenerated with Ipomoea pescaprae but in this study showed Prosopis juliflora and Opuntia dillenii were occupied the habitat. As previous research suggested $P$. juliflora and $O$. dillinii established very well in degraded coastal ecosystems due to high survival rate in the poor saline soil, high regeneration and the nature of invasive behavior (Dilhan, 2005, Chandrasekara et al., 2001, Seneviratne et al., 2001). Kahandamodara beach (Bambaradeniya et al. 2006) had high beach replenishment with $>60 \%$ plant regeneration with Ipomoea pes-caprae, Calotropis gigantea and Scaevola taccada. The dominant coastal shrub species recorded in this study area was Pandanus odoratissimus (Figure 5), which has high resistance potential for waves. The species composition changes after tsunami disaster have to be considered for best coastal management implications.

The kite flew in the coast at low altitude and obtained KAP at $4 \mathrm{~cm}$ spatial resolution, which was useful to make vegetation classification and sea level rise model using high-resolution DEM. Similarly, KAP has taken for mapping of intertidal landscapes at sub-centimeter resolution (Bryson et al., 2013), intertidal vegetation monitoring at $4 \mathrm{~cm}$ resolution (Pauly and Clerck, 2011) and ecological surveys of coral reef at $15 \mathrm{~cm}$ resolution (Currier, 2015). KAP has been utilized for several coastal applications to address the knowledge gaps. For example, this study was able to extract $P$. juliflora from KAP derived orthoimagery using feature extraction technique, which is useful to forest managers to apply management priority for controlling the species based on its invasiveness. Furthermore, the NDVI derived from this study can adopt to estimate biomass of $P$. juliflora as procedures described by Gunawardena et al. (2014). Furthermore, coupling NDVI with texture analysis was able to estimate mangrove extent in Rekawa, which is useful to monitor deforestation on mangrove vegetation and implementing best coastal conservation plans to mitigate human-induced pressures on coastal vegetation. Despite KAP advantages (low-cost, high spatial resolution, limited regulation) there are a few limitations, such as GPS not being available in low cost, lightweight cameras onboard as in unmanned aerial vehicle that can geotag each image and therefore many ground control points need geo-referencing KAP. This affected the creation of a DEM and some software (precision mapper) could not recognize KAP images due to an unbranded camera. Some mosaic images have holes and blur features cause errors when image analysis was applied. 
In addition, some human footprints and GCP markers deteriorate the image quality. Although with such limitations, we depicted multi-scale utility of KAP through our groundbreaking research. Furthermore, this preliminary study will be utilized to a larger scale study using UAV imageries to pinpoint GIS model and coastal recommendations to protect the Sri Lanka coastline from SLR and future tsunami damage.

\section{Conclusions}

Monitoring finer changes of vegetation and capturing micro-topographical features of coastal habitats are challenging with $30 \mathrm{~m}$ resolution Landsat images. However, high-resolution aerial imageries are the limited resource available freely for public and therefore we utilized KAP for vegetation bioshield mass assessment using automated image analysis methods. This study estimated $P$. juliflora extent in coastal habitat using feature extraction and supervised classification methods, which is useful to forest managers to find out critical areas for conservation priorities. The mangrove vegetation delineation using KAP derived NDVI is precise due to high spatial resolution $(\sim 4 \mathrm{~cm})$ compared to Landsat images that have moderate spatial resolution $(\sim 30 \mathrm{~m})$. Creating very high-resolution DEM using KAP is essential to see how coastal habitats are vulnerable to sea level rise. Overall, KAP has a great potential to bridge science with high spatial/temporal resolution in-situ data for coastal habitat monitoring, where our researchers can utilize the data within a low-cost budget.

\section{References}

Ameer, F., 2015. Physical impacts of Oluvil harbour. $5^{\text {th }}$ International Symposium 2015 - IntSym 2015, SEUSL, pp 450-461.

Bambaradeniya, C., Perera, S.,Samarawickrema, P., 2006. A rapid assessment of post-tsunami environmental dynamics in relation to coastal zone rehabilitation and development activities in the Hambantota District of Southern Sri Lanka. IUCN Occasional paper - No. 10.

Bryson, M., Duce, S., Harris, D., Webster, J.M., Thompson, A., Vila-Concejo, A., Williams, S.B., 2016. Geomorphic changes of a coral shingle cay measured using kite aerial photography. Geomorphology, 270, 1-8.

Bryson, M., Johnson-Roberson, M., Murphy, R. J., Bongiorno, D., 2013. Kite aerial photography for lowcost, ultra-high spatial resolution multi-spectral mapping of intertidal landscapes. PloS one, 8(9), e73550.

Bryson, M., Johnson-Roberson, M., Murphy, R., 2012. Low-cost, ultra-high spatial and temporal resolution mapping of intertidal rock platforms. International Archives of the Photogrammetry, Remote Sensing and Spatial Information Sciences, Volume XXXIX-B8, 2012XXII ISPRS Congress, 25 August - 01 September 2012, Melbourne, Australia, 243-248.

Cattermoul, N., Devendra, A., 2002. A measurement of the ecological footprint of shrimp farming in the Chilaw lagoon area, Fieldwork Report 2.3a, University of Portsmouth Cemare, 1-33.

Chandrasekara, C.M.C.P., Perera, G.A.D., Senevirathne, G., 2001. Effect of soil nutrient status on the invasion of Prosopis juliflora and Opuntia dillenii at Bundala National Park. Proceedings of the $57^{\text {th }}$ Annual Sessions of the Sri Lanka Association for the Advancement of Science.

Chen, M., Ye, C., 2014. Differences in pattern and driving forces between urban and rural settlements in the coastal region of Ningbo, China. Sustainability, 6(4), 1848-1867.

Currier K., 2015. Mapping with strings attached: Kite aerial photography of Durai Island, Anambas Islands, Indonesia, Journal of Maps, 11:4, 589-597, DOI: 10.1080/17445647.2014.925839.

Dellysse, J.E., Madurapperuma, B.D., 2017. Tsunami effects and mitigation results for South-east regions in Sri Lanka, ideaFest Conference, $21^{\text {st }}$ April 2017, $2^{\text {nd }}$ Floor Library, Humboldt State University.

Dellysse, J.E., Madurapperuma, B.D., Kuruppuarachchi, K.A.J.M. 2017. Preliminary study on biomass mapping along the coastal zone of Hambantota region, Sri Lanka using Landsat imagery, The Open University Research Sessions, $16^{\text {th }}$ and $17^{\text {th }}$ November $2017,497-500$. 
Dilhan, M.A.A., 2005. Vegetation structure and floristic composition in the irrigation extension area of the Lower Walawe Basin, Sri Lanka. M.Phil. Thesis, Postgraduate Institute of Science, University of Peradeniya.

Grinsted, A., Moore, J.C., Jevrejeva, S., 2010. Reconstructing sea level from paleo and projected temperatures 200 to 2100 AD. Climate Dynamics, doi: 10.1007/s00382-008-0507-2.

Gunawardena, A.R., Fernando, T.T., Nissanka, S.P., Dayawansa, N.D.K., 2015. Assessment of spatial distribution and estimation of biomass of Prosopis juliflora (Sw.) DC. In Puttlam to Mannar region of Sri Lanka using remote sensing and GIS. Tropical Agricultural Research. 25(2), 228239. DOI: http://doi.org/10.4038/tar.v25i2.8144

Illangasekare, T., Tyler, S.W., Clement, T.P., Villholth, K.G., Perera, A.P.G.R.L., Obeysekera, J., Gunatilaka, A., Panabokke, C.R., Hyndman, D.W., Cunningham, K.J., Kaluarachchi, J.J., 2006. Impacts of the 2004 tsunami on groundwater resources in Sri Lanka. Water Resources Research, 42(5): W05201.

Liquete, C., Piroddi, C., Drakou, E.G., Gurney, L., Katsanevakis, S., Charef, A., Egoh, B., 2013. Current status and future prospects for the assessment of marine and coastal ecosystem services: a systematic review. PloS one, 8(7), e67737.

Madurapperuma, B., Close, P., Fleming, S., Collin, M., Thuresson, K., Lamping, J., Dellysse, J., Cortenbach, J., 2018. Habitat mapping of Ma-le'l Dunes coupling with UAV and NAIP image. In Proceedings of the $2^{\text {nd }}$ International Electronic Conference on Remote Sensing, 22 March-5 April 2018; Sciforum Electronic Conference Series, Vol. 2, 2017, doi:10.3390/ecrs-2-05182

Madurapperuma, B.D., Dellysse, J.E., Zahir, I.L.M., Iyoob, A.L., 2017a. Mapping shoreline vulnerabilities using kite aerial photographs at Oluvil harbour in Ampara, $7^{\text {th }}$ International Symposium 2017 (IntSym2017)-SEUSL - 07 ${ }^{\text {th }} \& 08^{\text {th }}$ December 2017, 197-204.

Madurapperuma, B.D., Dellysse, J.E., Kuruppuarachchi, K.A.J.M., Dissanayake, G.K.P., 2017b. Mapping topographic and vegetation bioshield mass recovery along the shoreline using Kite Aerial Photography. Proceedings of the 22 ${ }^{\text {nd }}$ International Forestry and Environment Symposium 2017 of the Department of Forestry and Environmental Science, University of Sri Jayewardenepura, Sri Lanka. P.78.

O’Donnell, J.P., Schalles, J.F., 2016. Examination of abiotic drivers and their influence on Spartina alterniflora biomass over a twenty-eight year period using Landsat 5 TM satellite imagery of the Central Georgia Coast. Remote Sensing, 8(6), 477. doi:10.3390/rs8060477

Pauly, K., Clerck, O., 2011. Low-cost very high resolution intertidal vegetation monitoring enabled by near-infrared kite aerial photography. www.vliz.be/imisdocs/publications/225813.pdf

Savundranayagam, T., de Alwis, L., Joseph, L., Siripala, N., 1994. The Economic Significance of the Coastal Region of Sri Lanka, Working Paper No. 06, Coastal Conservation Department and the Coastal Resources Management Project, Sri Lanka.

Seneviratne, G.I., Algama, A.L.M.N.S., 2001. Invasive species Prosopis juliflora in the coastal region of Hambantota district. Sri Lankan Biodiversity Review 1, 79-83.

Srinivasan, G.N., Shobha, G., 2008. Statistical texture analysis. In Proceedings of world academy of science, engineering and technology, Vol. 36, 1264-1269.

Vo, Q.T., Oppelt, N., Leinenkugel, P., Kuenzer, C., 2013. Remote sensing in mapping mangrove ecosystems - An object-based approach. Remote Sensing, 5(1), 183-201.

Xie, Y., Sha, Z., Yu, M., 2008. Remote sensing imagery in vegetation mapping: a review. Journal of plant ecology, 1(1), 9-23. 